\title{
Postpartum ovarian activity in multiparous Holstein cows treated with bovine somatotropin and fed $n-3$ fatty acids in early lactation ${ }^{1}$
}

\author{
M. Carriquiry, ${ }^{2}$ C. R. Dahlen, $†$ W. J. Weber, ${ }^{*}$ G. C. Lamb, $\ddagger^{3}$ and B. A. Crooker ${ }^{* 4}$ \\ *Department of Animal Science, University of Minnesota, St. Paul 55108-6118 \\ †Northwest Research and Outreach Center, University of Minnesota, Crookston 56716-5000 \\ ¥North Central Research and Outreach Center, University of Minnesota, Grand Rapids 55744-3361
}

\begin{abstract}
Multiparous cows $(\mathrm{n}=59)$ were blocked by expected calving date and previous 305-d mature-equivalent milk yield and assigned randomly to a $2 \times 2$ factorial design to determine the effects of bovine somatotropin (bST; Posilac, Monsanto Animal Agricultural Group, St. Louis, MO) and dietary fat on ovarian activity during the first $90 \mathrm{~d}$ in milk (DIM). Diets that included whole, high-oil sunflower seeds [SS; $10 \%$ of dietary dry matter; rich in linoleic acid (18:2)] or a mixture of Alifet-High Energy and Alifet-Repro [AF; Alifet USA, Cincinnati, $\mathrm{OH} ; 3.5$ and $1.5 \%$ of dietary dry matter, respectively; protected source of linolenic (18:3), eicosapentaenoic, and docosahexaenoic fatty acids] were provided from calving. Diets were isocaloric at equal intakes, but AF provided more net energy for lactation at actual intakes (1.54 vs. $1.66 \mathrm{Mcal} / \mathrm{kg}$ of dry matter). Cows received 0 or $500 \mathrm{mg}$ of bST (N, Y) every $10 \mathrm{~d}$ from 12 to $70 \mathrm{DIM}$ and at 14-d intervals from 70 to 280 DIM. Breeding was initiated after 90 DIM. Follicular dynamics, luteal growth and development (15 to 90 DIM), and plasma progesterone concentrations (1 to 90 DIM) were evaluated (3 times per week). Days to first ovulation (33.6 \pm 1.4) and incidence of anovulation at 45 or 70 DIM did not differ among treatments. Interovulatory intervals were similar among treatments $(22.1 \pm 0.9 \mathrm{~d})$. Incidence of estrous cycles with 2 follicular waves was greater for SSY (71.0\%) and AFN (80.0\%) than for other groups, but more 3-wave cycles occurred with AFY (83.3\%).
\end{abstract}

\footnotetext{
Received September 1, 2008.

Accepted June 19, 2009.

${ }^{1}$ This work was supported in part by a Doctoral Dissertation Research Grant from the Graduate School at the University of Minnesota, a Hueg-Harrison Fellowship, and a Sigma Delta Epsilon Fellowship all awarded to M. Carriquiry. Support for the study was also provided by the Agricultural Experiment Station at the University of Minnesota (project number 16-46).

${ }^{2}$ Current address: Facultad de Agronomía, Avda. Garzón 810, 12900 Montevideo, Uruguay.

${ }^{3}$ Current address: University of Florida-NFREC, 3925 Highway 71 , Marianna, FL 32446.

${ }^{4}$ Corresponding author: crook001@umn.edu
}

Growth rate of the ovulatory follicle was greater for AF than SS (1.9 vs. $2.2 \pm 0.11 \mathrm{~mm} / \mathrm{d})$ and diameter of ovulatory follicles was larger for AFN than the other treatments (17.9 vs. $15.7 \pm 0.7 \mathrm{~mm})$. Area under the progesterone curve was reduced for SSY $(63.2,48.1$, 55.5 , and $61.4 \pm 5.1 \mathrm{ng} \cdot \mathrm{d} / \mathrm{mL}$ for SSN, SSY, AFN, and AFY, respectively). The number of class 1 (3 to $5 \mathrm{~mm}$ ) follicles was decreased and the number of class 2 (6 to $9 \mathrm{~mm}$ ) follicles was increased by bST. The number of class 2 follicles was reduced by AF. Initiation of bST administration at 12 DIM and dietary n-3 fatty acids altered ovarian activity during the first 90 DIM and could benefit reproductive performance. Dietary n-3 fatty acids interacted with bST administration in early lactation to increase the incidence of estrous cycles with 3 follicular waves. Although these changes could benefit reproductive performance, evaluation with a larger number of cows is needed to determine if these alterations improve fertility.

Key words: somatotropin, n-3 fatty acid, follicular dynamic

\section{INTRODUCTION}

Supplementation with dietary fat and administration of bST are management approaches that have the potential to improve the reproductive performance of high-producing dairy cows (Staples et al., 1998; Moreira et al., 2001). Several mechanisms have been proposed to explain the positive effects of supplemental fat on reproductive performance (Beam and Butler, 1997; Staples et al., 1998; Mattos et al., 2002). These include 1) increased LH secretion; 2) increased number and size of total and preovulatory follicles; 3) increased secretion, increased clearance, or increased secretion and clearance of progesterone $\left.\left(\mathbf{P}_{4}\right) ; 4\right)$ increased size and lifespan of the corpus luteum (CL); and 5) reduced $\mathrm{PGF}_{2 \alpha}$ synthesis and secretion. The effect of supplemental fats on reproductive function likely depends on the fatty acid composition and extent of ruminal biohydrogenation of the fat source (Staples et al., 1998; Petit et al., 2002, 2004). As milk production and management intensity 
have increased, feeding systems have evolved toward a greater use of dietary concentrates (rich in n-6), which has increased the dietary n- $6 / \mathrm{n}-3$ fatty acid ratio from 0.5 to 6 (Ponter et al., 2006), and this has been associated with reduced reproductive function (Mattos et al., 2002).

Several characteristics of reproductive function are improved when cows are treated with bST. These improvements have been linked with increased circulating concentrations of IGF-I and include an increased number of recruited follicles (Kirby et al., 1997), an increased size of the second largest follicle (De La Sota et al., 1993), an increased number of dominant follicles (Jimenez-Krassel et al., 1999), and increased ovulation rate (Jimenez-Krassel et al., 1999). Administration of bST decreased the interval between follicular waves by an earlier emergence of the second wave of follicular growth (Kirby et al., 1997; Lucy, 2000). In well-managed cows, bST increased pregnancy rates in a timed AI protocol and had a beneficial effect on the development of the preovulatory follicle, oocyte, or both (Moreira et al., 2001).

Our hypothesis was that dietary n-3 fatty acids and bST administration would alter follicular dynamics and that these alterations could help improve reproductive performance. No study appears to have examined the combined effects of source of supplemental fat and bST administration on ovarian activity of early postpartum cows. Therefore, the objective of this study was to evaluate the effects of bST and dietary fat enriched with n- 6 or n-3 fatty acids on ovarian activity in early postpartum dairy cows.

\section{MATERIALS AND METHODS}

\section{Animals, Experimental Design, and Treatments}

Animal care and experimental procedures were approved by the University of Minnesota Institutional Animal Care and Use Committee. Detailed descriptions of the diets, animal management, data and sample collection and analyses, and production responses have been reported (Carriquiry et al., 2009b). Briefly, multiparous cows $(\mathrm{n}=59)$ were fed a dry cow diet beginning $3 \mathrm{wk}$ before the expected calving date. Cows were blocked by expected calving date and previous milk yield (305-d mature-equivalent milk yield) and assigned randomly to 1 of 4 treatments in a $2 \times 2$ factorial arrangement of bST (0 or $500 \mathrm{mg} /$ injection) and source of supplemental dietary fat. Treatment diets contained either whole, high-oil (42\% ether extract) sunflower seeds (SS; $10 \%$ of dietary DM) as a source of linoleic acid (18:2; dietary $\mathrm{n}-6 / \mathrm{n}-3$ ratio $=4.6$ ) or a mixture of Alifet-High Energy and Alifet-Repro (AF; Alifet USA, Cincinnati, OH; 3.5 and $1.5 \%$ of dietary DM, respectively) as a source of $n-3$ fatty acids (dietary n- $6 / \mathrm{n}-3$ ratio $=2.6$ ). Alifet-High Energy is a microcrystallized rumen-inert energy concentrate made from animal fat $(99 \%)$ rich in saturated fatty acids (57\% stearic acid, 18:0; $25 \%$ palmitic acid, 16:0). Alifet-Repro is a microcrystallized rumen-inert fat (flaxseed oil and fish oil) that is enriched with the n-3 fatty acids linolenic $(18: 3 ; 15.7 \%)$, eicosapentanoic (EPA, 20:5; 1.3\%), and docosahexaenoic (DHA, 22:6; $1.3 \%$ ) acids. Treatment diets were offered from calving, and administration of bST (Posilac, Monsanto Animal Agricultural Group, St. Louis, MO) was initiated on $12 \pm 3$ DIM and continued at 10-d intervals through $70 \pm 3$ DIM and at 14-d intervals from 70 to $280 \pm 3$ DIM. Treatments from the $2 \times 2$ factorial arrangement of diets (SS, AF) with $0(\mathbf{N})$ or $500 \mathrm{mg}(\mathbf{Y})$ of bST per injection were designated SSN, SSY, AFN, and AFY, and there were 15, 16, 15, and 13 cows per treatment, respectively.

Cows were housed in tie stalls and fed individually. Diets were provided as TMR and were formulated to meet the nutritional needs of the cows. Treatment diets, composed primarily of alfalfa haylage, corn silage, high-moisture shelled corn, and soybean meal, were designed to differ primarily in the type of fatty acids they contained and were formulated to contain similar amounts of $\mathrm{NE}_{\mathrm{L}}(1.68$ and $1.71 \mathrm{Mcal} / \mathrm{kg}$ of $\mathrm{DM}$, respectively) at a predicted peak DMI of $29.9 \mathrm{~kg} / \mathrm{d}(4.7 \times$ maintenance) as described by Carriquiry et al. (2009b). The $\mathrm{NE}_{\mathrm{L}-\mathrm{Actual} \text { DMI }}$ values were 1.54 and $1.66 \mathrm{Mcal} / \mathrm{kg}$ of $\mathrm{DM}$ for $\mathrm{SS}$ and AF, respectively. The SS and AF diets contained 8.6 and $7.7 \%$ ether extract and an estimated 7.9 and $7.0 \%$ fatty acid (Allen, 2000) on a DM basis, respectively. Dietary content of all other major nutrients differed by $<4 \%$ and averaged $18.5 \% \mathrm{CP}, 18.5 \% \mathrm{ADF}$, and $28 \%$ NDF (Carriquiry et al., 2009b). Formulation differences altered the dietary linoleic acid (383 vs. 265 $\mathrm{mg} / \mathrm{g}$ of fatty acids), EPA (0.4 vs. $2.6 \mathrm{mg} / \mathrm{g}$ of fatty acids), and DHA (0.2 vs. $1.8 \mathrm{mg} / \mathrm{g}$ of fatty acids) content of the SS and AF diets, respectively (Carriquiry et al., 2009a). The n-3 fatty acids in Alifet-Repro were partially protected (75 to 95\%) from metabolism by rumen microorganisms (Carriquiry et al., 2008), which contributed to an increased proportion of these fatty acids in the milk from cows that consumed AF (Carriquiry et al., 2009a).

Cows were milked 2 times per day and BW, backfat thickness, and BCS were measured at weekly intervals from -2 to 4 wk of lactation and at 4 -wk intervals from 4 to $40 \mathrm{wk}$ of lactation (Carriquiry et al., 2009b). Amounts of feed offered and refused were recorded daily to determine feed intake. General health records were maintained throughout the study, and cows were treated for illness when warranted. Severity of health 
episodes during the first 28 DIM was scored as 0,1 , 2 , or 3 , which represented no health episodes, health episodes without a clear effect on DMI or milk yield, health episodes that lasted $<3 \mathrm{~d}$ with reduced DMI and milk yield for $<3 \mathrm{~d}$, or health episodes that lasted $3 \mathrm{~d}$ or more with reduced DMI and milk yield for $3 \mathrm{~d}$ or more, respectively.

Blood samples were collected every Wednesday through wk 24 of lactation and plasma was analyzed for IGF-I and glucose (Carriquiry et al., 2009b). From calving until 90 DIM, blood samples were collected every Monday, Wednesday, and Friday in Vacutainer tubes (Becton Dickinson, Franklin Lakes, NJ) that contained sodium fluoride $(2.5 \mathrm{mg} / \mathrm{mL}$ of blood $)$ and potassium oxalate $(2 \mathrm{mg} / \mathrm{mL}$ of blood). Blood was placed on ice and plasma was harvested within 60 min after collection $\left(2,000 \times g\right.$ for $15 \mathrm{~min}$ at $\left.4^{\circ} \mathrm{C}\right)$. Plasma was stored at $-20^{\circ} \mathrm{C}$ until analyzed for $\mathrm{P}_{4}$ by solid-phase RIA (Coat-A-Count Progesterone, DPC, Los Angeles, CA). Mean assay sensitivity was $0.02 \mathrm{ng} / \mathrm{mL}$ and intra- and interassay coefficients of variation were 6.1 and $5.9 \%$, respectively.

\section{Ultrasonography}

Ovarian structures were scanned and measured every Monday, Wednesday, and Friday by transrectal ultrasonography $(7.5-\mathrm{mHz}$ transrectal probe, Aloka 500V, Corimetrics, Wallingford, CT) from 15 to 17 DIM through 90 DIM. At each scan, the size and relative position of follicles and CL were measured and recorded on follicular maps, which allowed identification for subsequent analyses. Luteal volume was calculated as $\mathrm{V}=$ $4 / 3 \times \pi \times \mathrm{R}$, where the radius $(\mathrm{R})$ was calculated as $\mathrm{R}=(\mathrm{L} / 2+\mathrm{W} / 2) / 2$ and $\mathrm{L}$ and $\mathrm{W}$ were the measured length and width of the follicle. For CL with a fluidfilled cavity, volume of the cavity was calculated and subtracted from the total CL volume. Follicles were classified by size as class 1 ( 3 to $5 \mathrm{~mm}$ ), class 2 (6 to $9 \mathrm{~mm}$ ), class 3 (10 to $15 \mathrm{~mm})$, or class $4(>15 \mathrm{~mm})$ as described by Lucy et al. (1991).

Cystic structures were characterized as follicular structures that exceeded $25 \mathrm{~mm}$ in diameter and persisted for $\geq 10 \mathrm{~d}$ in the absence of a CL (Garverick, 1997). A persistent CL was defined as a luteal structure that remained detectable on the ovary for $\geq 30 \mathrm{~d}$ and that maintained serum $\mathrm{P}_{4}$ concentrations above $1 \mathrm{ng} /$ $\mathrm{mL}$. Ovulation or disappearance of a dominant follicle and appearance of a CL was confirmed by a subsequent increase in plasma $\mathrm{P}_{4}$ above the threshold value of $1 \mathrm{ng} /$ $\mathrm{mL}$. The average number of days between a recorded estrus and $\mathrm{P}_{4}$ increase above $1 \mathrm{ng} / \mathrm{mL}$ was $4.1 \pm 0.18$ $\mathrm{d}(\mathrm{n}=33)$, and day of ovulation was estimated as $4 \mathrm{~d}$ before this increase in $\mathrm{P}_{4}$. Multiple ovulations were de- termined retrospectively by the presence of multiple CL when multiple dominant follicles had been detected in preovulatory ultrasound examinations. Luteolysis was considered as the day before serum $\mathrm{P}_{4}$ concentration decreased by more than $50 \%$ from the maximum $\mathrm{P}_{4}$ concentration in the cycle. Atypical cycles were defined as cycles in which the ovulatory wave began after luteolysis (Sartori et al., 2004).

\section{Calculations and Statistical Analyses}

Area under the $\mathrm{P}_{4}$ curve (AUC) was calculated by linear trapezoidal summation between successive pairs of $\mathrm{P}_{4}$ concentration and time coordinates. Data were analyzed using SAS (SAS Institute Inc., Cary, NC). Effects of treatment on number of cycles per cow during the first 90 DIM, interovulatory interval, day of luteolysis, days from luteolysis to ovulation, interval from emergence of the last wave to ovulation, size of the ovulatory follicle (at luteolysis and maximum), luteal tissue volume (mean and maximum), $\mathrm{P}_{4}$ concentrations (at luteolysis, mean, maximum, and AUC), and ovulation rate were analyzed in a randomized block design using the MIXED procedure (SAS Institute Inc.). The model included the effects of bST, diet, and their interaction as fixed effects and block as a random effect. Because some cows had more than 1 estrous cycle, the initial model included estrous cycle in a repeated measures analysis; however, the effect of estrous cycle was not significant and was therefore removed from the model.

Effects of treatment and time on luteal tissue volume (5- to 15-d estrous cycle), $\mathrm{P}_{4}$ concentration (from $\mathrm{d} 1$ to 15 of the estrous cycle, from $3 \mathrm{~d}$ before to $3 \mathrm{~d}$ after luteolysis, and during the $7 \mathrm{~d}$ before ovulation), diameter of the ovulatory follicle (from 1 to $6 \mathrm{~d}$ before ovulation and from $3 \mathrm{~d}$ before to $3 \mathrm{~d}$ after luteolysis), and number and diameter of follicles by class were analyzed in a randomized block design by repeated measures using the MIXED procedure (SAS Institute Inc.) with day of the estrous cycle, day to luteolysis, day to ovulation, or week of lactation as the repeated measure and with first-order autoregressive covariance structure specified. The model included the effects of bST, diet, their interaction, and day or week as fixed effects and block as a random effect. Effects of treatment on the incidence of anestrous cows at 45 and 70 DIM, incidence of short luteal phases, incidence of a persistent CL, incidence of cystic structures, and incidence of atypical cycles were analyzed with the NLMIXED procedure (SAS Institute Inc.). The model included bST, diet, and their interaction as fixed effects (converted to dummy variables) and block as a random effect. Effects of treatment on days to first ovulation were analyzed using the GENMOD procedure (SAS Institute Inc.) with the Poisson 
distribution specified in a model that included bST, diet, and their interactions. Effect of block was not significant and was therefore removed from the model. Effects of treatment on incidence of multiple ovulations and incidence of 2- or 3-wave cycles were analyzed by repeated measures using the GENMOD procedure (SAS Institute Inc.) with estrous cycle as the repeated measure and with the binomial distribution and an exchangeable covariance structure specified. The initial model included block, bST, diet, and their interaction. Effect of block was not significant $(P>0.25)$ and was therefore removed from the model.

Comparison of each outcome variable between estrous cycles with 2 or 3 follicular waves was performed as described previously, but the model included the number of waves as a fixed effect and block as a random effect. Correlation and linear regression coefficients were estimated using the CORR procedure and the REG procedure (SAS Institute Inc.) to describe relationships between reproductive measures and production responses and between follicular and CL dynamics, respectively. For all results, means were considered to differ when $P \leq 0.05$, and trends were identified when $0.05<P<0.10$.

\section{RESULTS}

\section{Production Response}

During the first 90 DIM, DMI increased $(P=0.001)$ and there was an interaction of diet, bST, and week of lactation $(P=0.039)$, which revealed a more rapid increase and greater DMI by the SSN cows than the others. Milk yield was increased $(P=0.001)$ by bST administration but was not altered $(P>0.19)$ by dietary fat source or the interaction of bST and fat source. Body condition score did not differ at the beginning of the study and the magnitude of BCS loss did not differ among treatments. The duration of negative energy balance, week of lactation of energy balance nadir, and magnitude of the nadir did not differ among treatments (Table 1). Mean energy balance was less $(P$ $=0.001)$ in cows treated with bST, and there was a trend $(P=0.058)$ for cows treated with bST to have a greater negative energy balance when they consumed the SS diet. Distribution of cows $(\mathrm{n}=38,9,6$, and 6$)$ among health episode severity classifications (0, 1, 2, and 3 , respectively) indicated no evidence of any effect of treatment on cow health (Carriquiry et al., 2009b). Duration of reduced milk and DMI for the 6 class-3 health episodes was $3,4,5,6$, and $7 \mathrm{~d}$ for $2,1,1,1$, and 1 cow, respectively.

\section{Ovarian Activity-First 90 DIM}

Interval from calving to first ovulation (Table 2) was not affected by treatment $(P>0.34)$. Interval from calving to first ovulation was not correlated $(P>0.19)$ with energy balance, BCS loss, or milk yield during the first 28 DIM whether all $(\mathrm{n}=59)$ or only healthy $(\mathrm{n}=$ 38) cows were considered. Nonetheless, interval to first ovulation was correlated $(\mathrm{r}=0.59, P<0.001)$ with the severity of the health episode during the first 28 DIM. Incidence of anovulation (Table 2) at $45(18.3 \%)$ or 70 (8.5\%) DIM was not affected by treatment $(P>0.36)$. Incidence of anovulation at 45 DIM was not associated $(P>0.75)$ with BCS loss or energy balance during the first 28 DIM, but the proportion of anovulatory cows at 45 DIM decreased as BCS at 28 DIM increased ( $\mathrm{y}=$ $\left.105.4-24.3 \mathrm{x} ; P<0.001 ; \mathrm{R}^{2}=0.75\right)$.

There were 115 completed estrous cycles during the first 90 DIM. The number of estrous cycles per cow $(2.0 \pm 0.3)$ and their duration $(19.5 \pm 0.9 \mathrm{~d})$ were not affected by treatment $(P>0.29$; Table 2$)$. The duration of the first estrous cycle was reduced $(P=0.032)$ in cows fed AF, but the duration of the second and third cycles was not altered $(P>0.19)$ by treatment. The incidence of short luteal phases $(<10 \mathrm{~d})$ did not differ $(P>0.62)$ among treatments (Table 2$)$. Most $(P<0.001)$ of the short luteal phases occurred during the first postpartum cycle (20 of 49 first cycles, 4 of 43 second cycles, and 0 of 23 third cycles). Therefore, the first postpartum cycle (from first to second ovulation) was shorter $(P<0.001)$ than the second or third postpartum cycles $(17.1,20.0$, and $21.3 \pm 0.8 \mathrm{~d}$, respectively).

The number of cycles with persistent CL (prolonged luteal phases $)$ did not differ $(P>0.54)$ among treatments (Table 2). A persistent CL occurred in 9 of 115 completed estrous cycles during the first 90 DIM, and 5 other persistent cycles were incomplete at 90 DIM. Most of the prolonged cycles (12 of $14 ; P<0.001$ ) developed in the first postpartum cycle. Incidence of cystic structures $(8.4 \%)$ did not differ $(P>0.86)$ among treatments (Table 2) and half (5 of 10) occurred before the first postpartum ovulation. A total of 9 follicular cysts and 1 luteal cyst occurred during the first 90 DIM, and these were not included in the number of completed cycles. The number of multiple ovulations did not differ $(P>$ $0.35)$ between the first, second, and third postpartum estrous cycles and was not affected $(P>0.26)$ by diet. Administration of bST (Table 2) tended to increase the incidence of multiple ovulations (10.0 vs. $20.4 \%, P=$ $0.10)$ and the number of follicles that ovulated per cycle (1.09 vs. $1.21 \pm 0.04, P=0.062)$. During the first $4 \mathrm{wk}$ of lactation, plasma IGF-I concentrations tended $(P<$ $0.06)$ to be greater $(82.7 \mathrm{vs} .72 .1 \pm 5.6 \mathrm{ng} / \mathrm{mL})$ in cows that cycled before 45 DIM than in cows that were not cycling by 45 DIM (data not presented).

During the first $90 \mathrm{DIM}$, the number of class 1 follicles did not differ $(P=0.81)$ between diets but was 


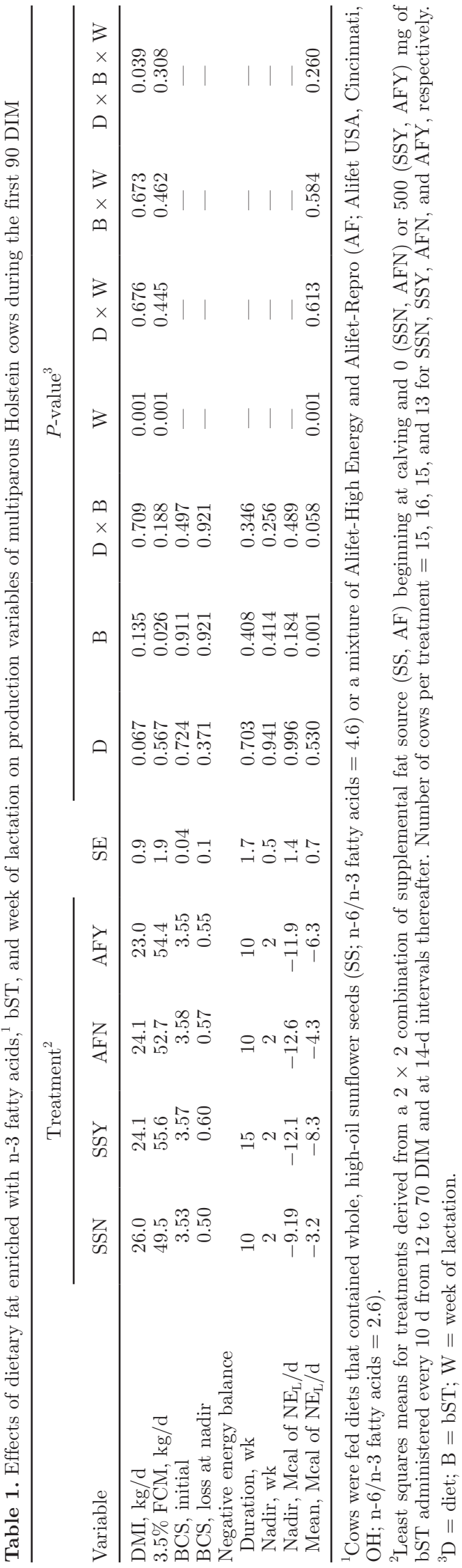

decreased $(P=0.013)$ by bST, and there was an interaction of diet and bST $(P=0.015)$ because AFN cows had the most and AFY had the fewest class 1 follicles (Table 3). The number of class 2 follicles decreased $(P$ $=0.041)$ in cows fed AF compared with SS (1.7 vs. $1.5 \pm 0.06$ follicles/cow $)$ and increased $(P=0.031)$ in cows treated with bST (1.5 vs. $1.7 \pm 0.06$ follicles/ cow) compared with cows not treated with bST. The number of class 3 follicles did not differ $(P=0.49)$ between diets, but tended $(P=0.075)$ to increase with bST administration and increased $(P=0.020)$ as lactation progressed. When combined, the number of class 2 and class 3 follicles was increased $(P<0.003)$ by bST. Neither diet nor bST affected the number of class 4 follicles (1.2 \pm 0.1 follicles/cow) or the mean size of class $2(7.7 \pm 0.09 \mathrm{~mm})$, class $3(12.5 \pm 0.09 \mathrm{~mm})$, or class $4(17.8 \pm 0.09 \mathrm{~mm})$ follicles. The number of follicles with a diameter $>10 \mathrm{~mm}$ (class 3 and class 4 ) increased $(P<0.001)$ from 1 follicle/cow in early lactation to a plateau of 3 follicles/cow by wk 7 of lactation $(\mathrm{y}=0.23$ $\left.+0.50 \mathrm{x}-0.02 \mathrm{x}^{2}, P<0.001, \mathrm{R}^{2}=0.62\right)$.

\section{Ovarian Activity-Normal Estrous Cycles}

Eighty-two of the 115 estrous cycles during the first 90 DIM had luteal phases of normal length (between 10 and $30 \mathrm{~d}$ ) and 6 of these 82 estrous cycles were classified as atypical. Therefore, 76 normal estrous cycles were included in the analysis of ovarian activity (Table $4)$. Incidence of normal estrous cycles $(92.7 \%, P>0.62)$ and the interovulatory interval for normal cycles $(22.1$ $\pm 0.9 \mathrm{~d}, P>0.28)$ did not differ among treatments (Table 4). No estrous cycles with 1 or 4 follicular waves were observed and the proportion of 2 -wave $(51 \%)$ and 3 -wave $(49 \%)$ cycles was similar. Administration of bST decreased $(P=0.041)$ and $\mathrm{AF}$ tended $(P=0.061)$ to decrease the incidence of estrous cycles with 2 follicular waves. There were interactions $(P<0.001)$ of diet and bST because bST increased the proportion of 3 -wave cycles in cows fed AF, but not in cows fed SS (Table 4). There was an effect of estrous cycle number because the incidence of 2 -wave cycles increased $(P=0.05)$ from the second to third estrous cycle (data not presented).

Day of luteolysis $(17.8 \pm 0.9 \mathrm{~d})$ and interval from luteolysis to ovulation $(5.2 \pm 0.6 \mathrm{~d})$ were not affected by treatment $(P>0.52)$ or their interaction $(P>0.15$; Table 4). Most cows (92\%) with normal cycles ovulated between 2 and $7 \mathrm{~d}$ after luteolysis. There was an interaction of diet and bST $(P=0.037)$ because the maximum diameter of the ovulatory follicle was greater in AFN cows than in SSN, SSY, or AFY cows. An effect of treatment on the development of the largest dominant follicle in an ovulatory wave depended on how the data were normalized. When normalized to the day of lute- 
Table 2. Effect of dietary fat enriched with n-3 fatty acids ${ }^{1}$ and bST administration on reproductive measures during the first 90 DIM in multiparous Holstein cows

\begin{tabular}{|c|c|c|c|c|c|c|c|c|}
\hline \multirow[b]{2}{*}{ Variable } & \multicolumn{4}{|c|}{ Treatment $^{2}$} & \multirow[b]{2}{*}{$\mathrm{SE}$} & \multicolumn{3}{|c|}{$P$-value ${ }^{3}$} \\
\hline & SSN & SSY & $\mathrm{AFN}$ & $\mathrm{AFY}$ & & $\mathrm{D}$ & $\mathrm{B}$ & $\mathrm{D} \times \mathrm{B}$ \\
\hline Days from calving to first ovulation & 32.7 & 33.9 & 33.9 & 33.8 & 1.4 & 0.645 & 0.906 & 0.343 \\
\hline Anestrous cows at 45 DIM, $\%$ (no./no.) & $13.3(2 / 15)$ & $18.8(3 / 16)$ & $20.0(3 / 15)$ & $7.7(1 / 13)$ & & 0.696 & 0.906 & 0.366 \\
\hline Anestrous cows at 70 DIM, \% (no./no.) & $6.7(1 / 15)$ & $12.5(2 / 16)$ & $13.3(2 / 15)$ & $0.0(0 / 13)$ & & 0.571 & 0.539 & 0.996 \\
\hline Completed estrous cycles, no. & 31 & 28 & 30 & 26 & 0.3 & 0.593 & 0.759 & 0.594 \\
\hline Completed cycles per cow (first 90 DIM), no. & 2.1 & 1.8 & 2.0 & 2.0 & & 0.593 & 0.759 & 0.594 \\
\hline Cycles with a short luteal phase $(<10 \mathrm{~d}){ }^{4}$ no. & 6 & 5 & 6 & 7 & & 0.852 & 0.786 & 0.623 \\
\hline Cycles with a persistent corpus luteum $(>30 \mathrm{~d}){ }^{4,5}$ no. & $\begin{array}{l}0 \\
3\end{array}$ & 4 & 2 & 0 & & 0.659 & 0.644 & 0.110 \\
\hline Cycles with a luteal phase $(10$ to $30 \mathrm{~d})$, no. & 22 & 19 & 22 & 19 & & 0.954 & 0.616 & 0.948 \\
\hline \multicolumn{9}{|l|}{ Duration of estrous cycles, $d$} \\
\hline Mean $^{4}$ & 20.3 & 19.3 & 18.8 & 19.5 & 0.9 & 0.434 & 0.846 & 0.292 \\
\hline First estrous cycle & 19.2 & 19.0 & 15.7 & 14.2 & 1.9 & 0.032 & 0.656 & 0.727 \\
\hline Second and third estrous cycles & 20.4 & 19.4 & 20.2 & 21.4 & 0.9 & 0.228 & 0.946 & 0.194 \\
\hline Ovarian cysts, ${ }^{6}$ no. & $\begin{array}{c}20.4 \\
2\end{array}$ & $\begin{array}{c}19.4 \\
4\end{array}$ & 3 & 1 & & 0.855 & 0.896 & 0.892 \\
\hline Multiple ovulations, no. & 3 & 5 & 3 & 6 & & 0.647 & 0.100 & 0.759 \\
\hline Ovulatory follicles/cycle & 1.1 & 1.2 & 1.1 & 1.3 & 0.1 & 0.255 & 0.062 & 0.702 \\
\hline
\end{tabular}

${ }^{1}$ Cows were fed whole, high-oil sunflower seeds (SS; n-6/n-3 fatty acids = 4.6) or a mixture of Alifet-High Energy and Alifet-Repro (AF; Alifet USA, Cincinnati, OH; n-6/n-3 fatty acids $=2.6)$.

${ }^{2}$ Data represent treatment least squares means from a $2 \times 2$ combination of supplemental fat source (SS, AF) beginning at calving and with 0 (SSN, AFN) or 500 (SSY, AFY) mg of bST administered every $10 \mathrm{~d}$ from 12 to 70 DIM and at 14-d intervals thereafter. Number of cows per treatment = 15, 16, 15, and 13 for SSN, SSY, AFN, and AFY, respectively. ${ }^{3} \mathrm{D}=$ diet; $\mathrm{B}=\mathrm{bST}$.

0.001. The first postpartum cycle (from first to second ovulation) was shorter than the second (from second to third ovulation) or the third (from third to fourth ovulation) cycle $(17.1,20.2,21.3+0.77 \mathrm{~d})$. Most of the short luteal phases occurred during the first postpartum cycle $(20$ of 54 first cycles, 4 of 43 second cycles, and 0 of 23 third cycles, and most of the persistent corpus luteum developed during the first postpartum cycle (12 of 14).

을 ${ }^{5}$ There were 5 additional incomplete persistent cycles $(1,1,0$, and 3 for SSN, SSY, AFN, and AFY, respectively) that extended beyond 90 DIM. The $P$-values for D, B, and D $\times$ B for all 14 persistent cycles were $0.535,0.691$, and 0.878 , respectively).

黕. $\quad{ }^{6}$ Not included in the total number of cycles because there was no ovulation. 
Table 3. Effect of dietary fat enriched with n-3 fatty acids ${ }^{1}$ and bST administration on the follicular population in cycling multiparous Holstein cows during the first $90 \mathrm{DIM}$

\begin{tabular}{|c|c|c|c|c|c|c|c|c|c|}
\hline \multirow[b]{2}{*}{ Variable } & \multicolumn{4}{|c|}{ Treatment $^{2}$} & \multirow[b]{2}{*}{$\mathrm{SE}$} & \multicolumn{4}{|c|}{$P$-value ${ }^{3}$} \\
\hline & SSN & SSY & $\mathrm{AFN}$ & $\mathrm{AFY}$ & & $\mathrm{D}$ & B & $\mathrm{D} \times \mathrm{B}$ & W \\
\hline \multicolumn{10}{|l|}{ Follicle no. } \\
\hline Class 1,3 to $5 \mathrm{~mm}$ & $7.5^{\mathrm{ab}}$ & $7.5^{\mathrm{ab}}$ & $8.7^{\mathrm{a}}$ & $6.5^{\mathrm{b}}$ & 0.5 & 0.807 & 0.013 & 0.015 & 0.159 \\
\hline Class 2,5 to $10 \mathrm{~mm}$ & 1.5 & 1.8 & 1.5 & 1.6 & 0.1 & 0.041 & 0.031 & 0.204 & 0.515 \\
\hline Class 3,10 to $15 \mathrm{~mm}$ & 1.3 & 1.4 & 1.3 & 1.4 & 0.1 & 0.490 & 0.075 & 0.968 & 0.020 \\
\hline Class $4,>15 \mathrm{~mm}$ & 1.2 & 1.2 & 1.2 & 1.2 & 0.1 & 0.406 & 0.826 & 0.559 & 0.890 \\
\hline Class 3 & 12.4 & 12.5 & 12.5 & 12.6 & 0.1 & 0.281 & 0.373 & 0.854 & 0.818 \\
\hline Class 4 & 17.8 & 17.8 & 17.3 & 18.0 & 0.4 & 0.655 & 0.230 & 0.255 & 0.304 \\
\hline
\end{tabular}

${ }^{\mathrm{a}, \mathrm{b}}$ Means with different superscripts within a row differ, $P<0.05$.

${ }^{1}$ Cows were fed whole, high-oil sunflower seeds (SS; n-6/n-3 fatty acids = 4.6) or a mixture of Alifet-High Energy and Alifet-Repro (AF; Alifet USA, Cincinnati, OH; n-6/n-3 fatty acids = 2.6).

${ }^{2}$ Data represent least squares means from treatments derived from a $2 \times 2$ combination of supplemental fat source (SS, AF) beginning at calving and with 0 (SSN, AFN) or 500 (SSY, AFY) mg of bST administered every 10 d from 12 to 70 DIM and at 14-d intervals thereafter. Number of cows per treatment $=15,16,15$, and 13 for SSN, SSY, AFN, and AFY, respectively.

${ }^{3} \mathrm{D}=\operatorname{diet} ; \mathrm{B}=\mathrm{bST} ; \mathrm{W}=$ week of lactation.

Table 4. Effect of dietary fat enriched with n-3 fatty acids ${ }^{1}$ and bST administration on follicular dynamics, luteal development, and plasma progesterone $\left(\mathrm{P}_{4}\right)$ concentration of normal ${ }^{2}$ estrous cycles during the first 90 DIM in multiparous Holstein cows

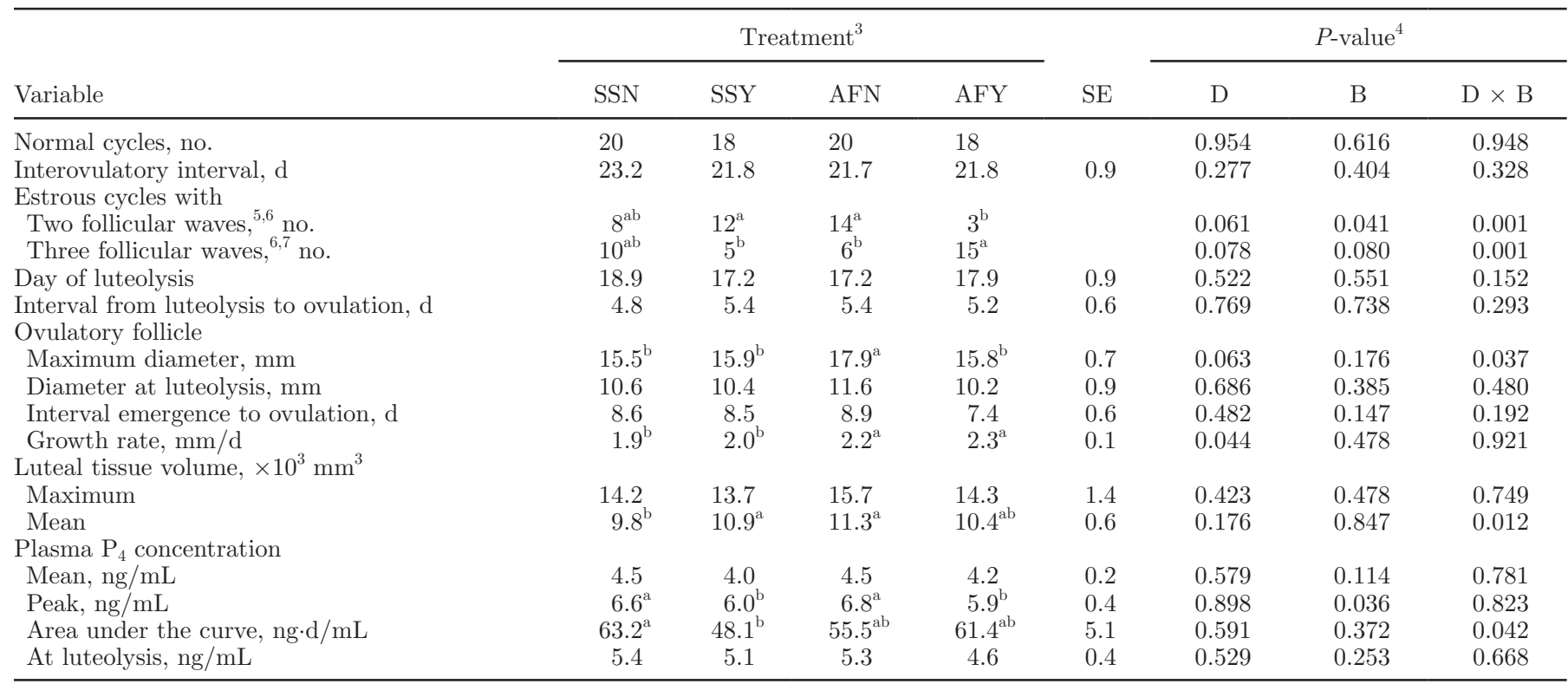

${ }^{\mathrm{a}, \mathrm{b}}$ Means with different superscripts within a row differ, $P<0.05$.

${ }^{1}$ Cows were fed whole, high-oil sunflower seeds (SS; n-6/n-3 fatty acids = 4.6) or a mixture of Alifet-High Energy and Alifet-Repro (AF; Alifet USA, Cincinnati, OH; n-6/n-3 fatty acids $=2.6$ ).

${ }^{2}$ Normal estrous cycles were defined as cycles with a luteal phase between 10 and $30 \mathrm{~d}$ and in which the ovulatory wave was present at luteolysis. There were 2, 2, 1, and 1 cycles with a luteal phase between 10 and $30 \mathrm{~d}$ but no ovulatory wave at luteolysis for SSN, SSY, AFN, and AFY, respectively.

${ }^{3}$ Data represent least squares means from treatments derived from a $2 \times 2$ combination of supplemental fat source (SS, AF) beginning at calving and with 0 (SSN, AFN) or 500 (SSY, AFY) mg of bST administered every $10 \mathrm{~d}$ from 12 to 70 DIM and at 14-d intervals thereafter. Number of cows per treatment $=15,16,15$, and 13 for SSN, SSY, AFN, and AFY, respectively.

${ }^{4} \mathrm{D}=$ diet; $\mathrm{B}=\mathrm{bST}$

${ }^{5}$ Estrous cycle effect, $P<0.05$. The incidence of 2 -wave cycles increased from the second to third estrous cycle (48.6 vs. $\left.61.9 \%\right)$.

${ }^{6}$ Wave analyses of 2 SSN cows and 1 SSY cow were not conducted because the cows had a corpus luteum when ultrasound was initiated at 15 DIM.

${ }^{7}$ Estrous cycle effect, $P<0.10$. The incidence of 3 -wave cycles tended to decrease from the second to third estrous cycle (51.4 vs. $38.1 \%$ ). 
A

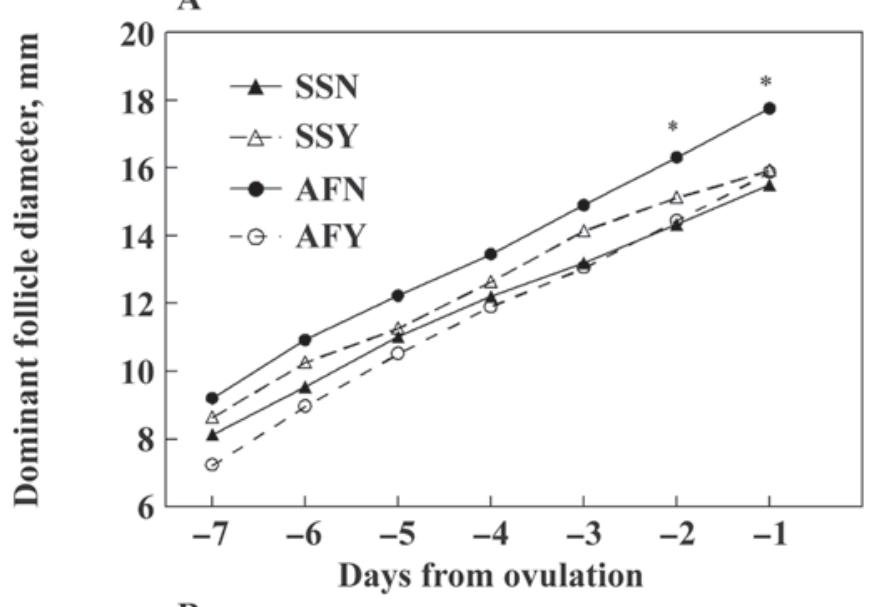

B

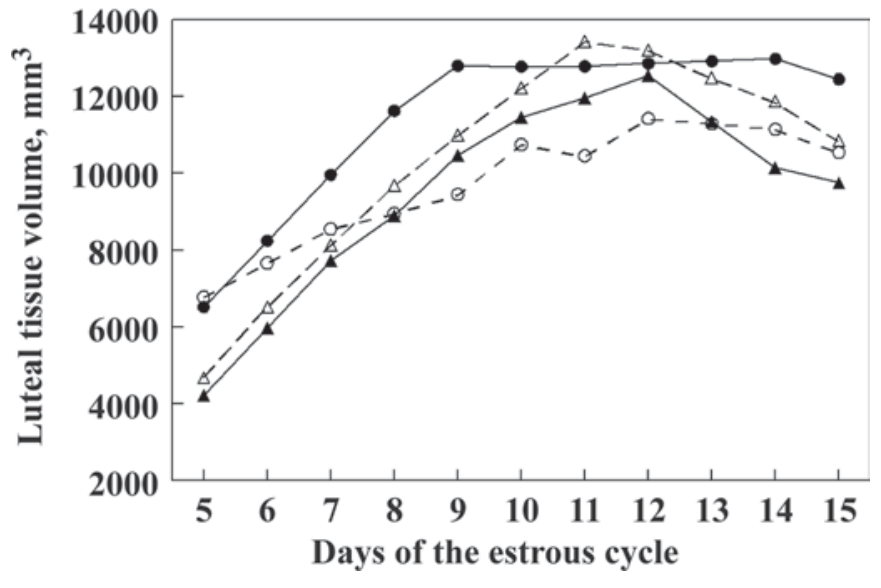

Figure 1. Effect of dietary fat enriched with n-3 fatty acids and bST administration on dominant follicle diameter normalized to day of ovulation (A) and on luteal tissue volume from d 5 to 14 of the estrous cycle (B) in multiparous Holstein cows with estrous cycles with a luteal phase between 10 and $30 \mathrm{~d}$ and in which the ovulatory wave was present at luteolysis. Cows were fed whole, high-oil sunflower seeds (SS; n-6/n-3 fatty acids $=4.6$ ) or a mixture of Alifet-High Energy and Alifet-Repro (AF; Alifet USA, Cincinnati, OH; n-6/n-3 fatty acids = 2.6) from calving. Treatments were derived from a $2 \times 2$ combination of supplemental fat source (SS, AF) and with 0 (SSN, AFN) or 500 (SSY, AFY) mg of bST administered every $10 \mathrm{~d}$ from 12 to 70 DIM and at 14-d intervals thereafter. Data are from 20,18, 20, and 18 estrous cycles from SSN, SSY, AFN, and AFY cows, respectively. Standard error of the mean was $0.8 \mathrm{~mm}$ for dominant follicle diameter and $1,094 \mathrm{~mm}^{3}$ for luteal tissue volume. ${ }^{*}$ Diameter of the dominant follicle was larger $(P<0.05)$ by $2 \mathrm{~d}$ before ovulation in AFN cows than in other cows. There was an interaction $(P=0.032)$ of diet and day of the estrous cycle on luteal tissue volume because cows fed AF had a larger corpus luteum early in the cycle (on d 5 and 6 of the cycle) that reached a plateau of maximum volume between d 9 or 10 of the cycle, whereas the luteal tissue volume of cows fed SS peaked between d 11 and 12 of the cycle and declined thereafter.

olysis, diameter of the largest dominant follicle did not differ $(P>0.37)$ among treatments. When normalized to day of ovulation, follicles in AFN cows were larger $(P<0.05)$ at 2 and $1 \mathrm{~d}$ before ovulation than those in other treatment groups (Figure 1A). The interval from follicle emergence to ovulation was not altered by treatment (Table 4). Although only AFN cows had larger ovulatory follicles, growth rate of the ovulatory follicle (Table 4$)$ was greater $(P=0.044)$ in cows fed AF $(1.9$ vs. $2.2 \pm 0.11 \mathrm{~mm} / \mathrm{d})$ than in those fed SS.

The maximum volume of luteal tissue did not differ $(P>0.42)$ among treatments (Table 4$)$. There was an interaction $(P=0.012)$ of diet and bST on mean diameter of the CL because bST increased the CL diameter in SS cows, but not in AF cows (Table 4). There was an interaction $(P=0.032)$ of diet and day of the estrous cycle on luteal tissue volume (Figure 1B) because cows fed $\mathrm{AF}$ had a larger $\mathrm{CL}$ early in the cycle (on d 5 and 6 of the cycle) that reached a plateau of maximum volume between d 9 and 10 of the cycle, whereas luteal tissue volume of cows fed SS peaked between d 11 and 12 of the cycle and declined thereafter.

Mean plasma $\mathrm{P}_{4}$ concentrations did not differ $(P>$ 0.11 ) among treatments. Administration of bST reduced $(P=0.036)$ peak concentration of $\mathrm{P}_{4}(6.7$ vs. 6.0 $\pm 0.3 \mathrm{ng} / \mathrm{mL})$. There was an interaction $(P=0.042)$ of diet and bST on $\mathrm{P}_{4}$ AUC in which bST reduced the $\mathrm{P}_{4}$ AUC in SS cows, but not in AF cows (Table 4). Despite differences in the $\mathrm{P}_{4}$ peak and AUC, $\mathrm{P}_{4}$ at luteolysis was not altered $(P>0.25)$ by treatment. Circulating $\mathrm{P}_{4}$ concentrations were not altered $(P>$ 0.22 ) by treatment or an interaction of treatment with day during the first $15 \mathrm{~d}$ of the estrous cycle, from 7 to $1 \mathrm{~d}$ before ovulation, or from $3 \mathrm{~d}$ before to $3 \mathrm{~d}$ after luteolysis $(3.35 \pm 0.25,3.57 \pm 0.38,4.30 \pm 0.40 \mathrm{ng} / \mathrm{mL}$, respectively).

There was a positive correlation between maximum diameter of the ovulatory follicle and luteal tissue volume at $\mathrm{d} 5$ of the estrous cycle $(\mathrm{r}=0.40, P=0.036$; Figure 2A) and between luteal tissue volume and plasma $\mathrm{P}_{4}$ at $\mathrm{d} 5$ of the estrous cycle $(\mathrm{r}=0.52, P<0.001$; Figure 2B). The slope of the linear regression between plasma $\mathrm{P}_{4}$ concentration and luteal tissue volume at $\mathrm{d}$ 5 of the estrous cycle was greater $(P<0.05)$ for cows not treated with bST (Figure 2B).

Day of luteolysis $(P=0.131)$ and interval from luteolysis to ovulation $(P=0.276)$ were not affected by the number of follicular waves per cycle, but cows with 3 -wave cycles had longer $(P=0.024)$ interovulatory intervals than cows with 2 -wave cycles (Table 5 ). The maximum diameter of the follicle $(P=0.026)$ and the diameter of the follicle at luteolysis $(P<0.001)$ were greater in 2 -wave cycles (Table 5 ). The interval from follicle emergence to ovulation was greater $(P<$ 0.001 ) for follicles in 2-wave cycles, so growth rate of the ovulatory follicle did not differ $(P=0.238)$ between 2 - and 3 -wave cycles (Table 5, Figures $3 \mathrm{~A}$ and $3 \mathrm{~B}$ ). Mean luteal tissue volume was greater $(P<0.001)$ for 2 -wave than for 3 -wave cycles (Table 5 ). This effect on 
A
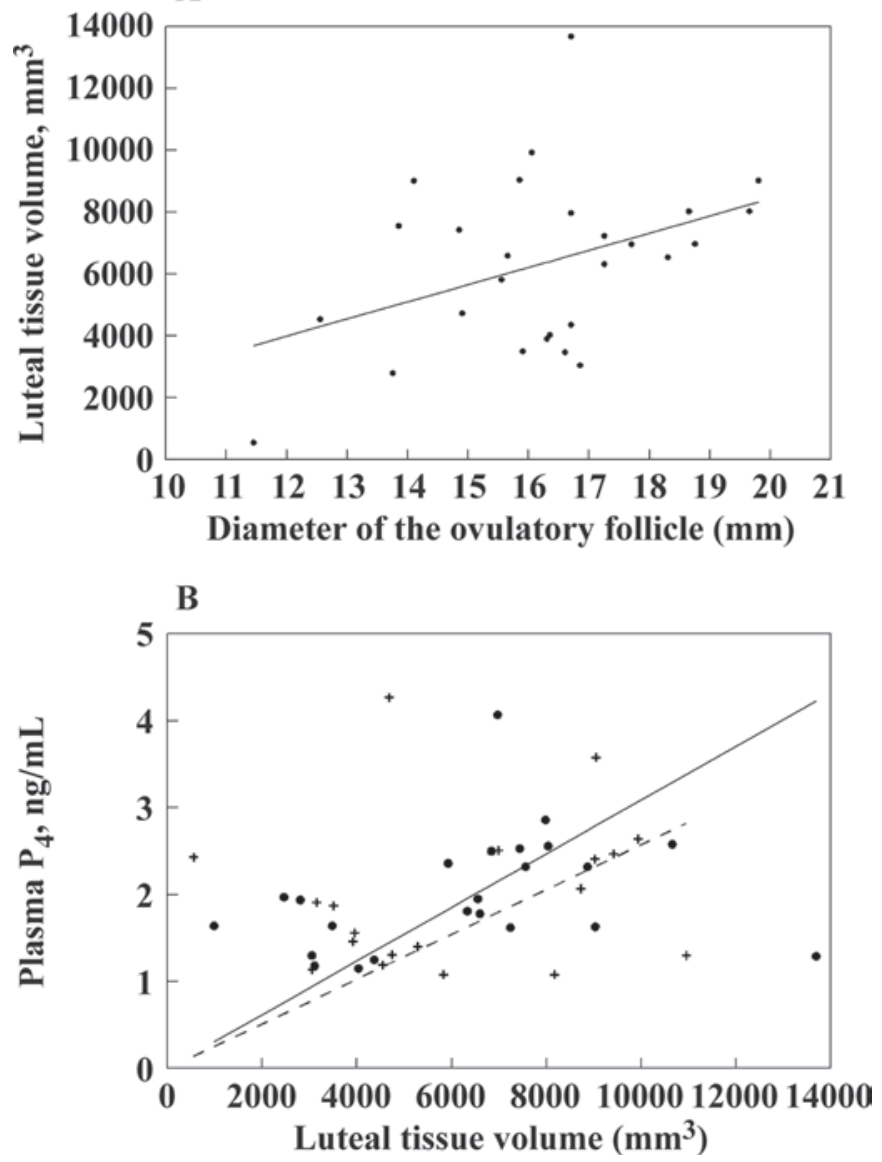

Figure 2. Linear relationship between maximum diameter of the ovulatory follicle (FOL) and luteal tissue volume at $\mathrm{d} 5$ of the estrous cycle $\left(\mathrm{A} ;\right.$ corpus luteum $=-2,261+550 \mathrm{FOL} ; P=0.036 ; \mathrm{R}^{2}=0.16$; $\mathrm{n}=27)$ and between luteal tissue volume and plasma progesterone $\left(\mathrm{P}_{4}\right)$ concentration at $\mathrm{d} 5$ of the estrous cycle (B) during the first 90 DIM for multiparous Holstein cows with a luteal phase between 10 and $30 \mathrm{~d}$ and in which the ovulatory wave was present at luteolysis. Cows were from 4 treatments derived from a $2 \times 2$ combination of supplemental fat source [whole, high-oil sunflower seeds (n-6/n-3 fatty acids $=4.6$ ) or a mixture of Alifet-High Energy and Alifet-Repro (Alifet USA, Cincinnati, OH; n-6/n-3 fatty acids = 2.6)] beginning at calving and with 0 or $500 \mathrm{mg}$ of bST administered every $10 \mathrm{~d}$ from 12 to 70 DIM and at 14-d intervals thereafter. Slope of the linear regression (B) forced through the origin was $0.258 \times 10^{-3}$ and $0.309 \times 10^{-3}$ for bST-treated $\left(P=0.025 ; \mathrm{R}^{2}=0.21 ; \mathrm{n}=22 ;\right.$ plus symbols and dashed line $)$ and untreated $\left(P<0.001 ; \mathrm{R}^{2}=0.36 ; \mathrm{n}=23\right.$; solid circles and solid line) cows, respectively. Fat source did not affect $(P>0.45)$ the relationship.

luteal volume was first detected on $\mathrm{d} 8$ of the estrous cycle (Figure 3C; $P<0.044$ ). Mean and peak plasma $\mathrm{P}_{4}$ concentrations, $\mathrm{P}_{4}$ concentrations during the first 15 $\mathrm{d}$ of the estrous cycle, and $\mathrm{P}_{4}$ AUC did not differ $(P$ $>0.21$ ) between 2 - and 3 -wave cycles (Table 5, Figure $3 \mathrm{D})$. Plasma $\mathrm{P}_{4}$ concentrations at luteolysis did not differ between 2 - and 3 -wave cycles (Table 5 ).

\section{DISCUSSION}

\section{Ovarian Activity-First 90 DIM}

The interval to first postpartum ovulation is considered an important measure of reproductive efficiency because cows must resume ovarian activity before breeding and because early postpartum return to cyclicity is associated with improved fertility and overall reproductive performance. The number of days to first postpartum ovulation $(33.6 \pm 1.4 \mathrm{~d})$ was not altered by diet or bST and was comparable with previous estimates in cows that produced large quantities of milk (Opsomer et al., 2000). Moallem et al. (1997) evaluated the effects of a factorial combination of bST (initiated at 10 DIM) and dietary fat (calcium soaps of long-chain fatty acids) in Holsteins and reported no difference in days to first ovulation $(26.8 \pm 9.2 \mathrm{~d})$. Interval to first postpartum ovulation was not correlated with energy balance characteristics, BCS loss, or milk yield during the first 28 DIM. Although interval to first postpartum ovulation was associated with negative energy balance (Lucy et al., 1991) and with days to negative energy balance nadir (Beam and Butler, 1997), energy balance explained only a small proportion of the variation $(P$ $<0.01 ; \mathrm{R}^{2}=0.10$ to 0.18 ), which indicated that other factors have important effects on the interval to first ovulation. Although only 6 cows in our study had health episodes that affected milk yield and DMI for longer than $3 \mathrm{~d}$, our results support the association between decreased reproductive performance and incidence of puerperal disorders and clinical diseases during the first month of lactation (Opsomer et al., 2000).

The incidence of anovulation at 70 DIM (8.5\%) was less than reported (15 to 28\%) for multiparous cows (Moreira et al., 2001). Despite producing an average of $45.0 \mathrm{~kg}$ of $\mathrm{FCM} / \mathrm{d}$ during the $280-\mathrm{d}$ study, no cow in our study lost more than 0.75 units and most $(90 \%)$ lost less than 0.5 units of BCS during the first 28 DIM. These small changes in BCS likely contribute to why BCS loss during the first 28 DIM was not associated with the interval to first ovulation or the incidence of anovulation.

Prolonged and short luteal phases are indicators of ovarian dysfunction and occur when the luteolytic cascade is disrupted. Our results support those of Santos et al. (2000), who reported that most of these abnormalities or disturbances occurred during the first postpartum estrous cycle and that most cows regained normal ovarian follicular dynamics during or after the second postpartum ovulation. The incidence of cystic structures (8.4\%) and persistent CL during the first postpartum cycle $(22 \%)$ in our study support previous estimates for dairy cows (Garverick, 1997). Most of the 
Table 5. Effect of number of follicular waves per estrous cycle on follicular growth, luteal development, and plasma progesterone $\left(\mathrm{P}_{4}\right)$ concentration in normal ${ }^{1}$ estrous cycles during the first 90 DIM in multiparous Holstein cows

\begin{tabular}{|c|c|c|c|c|}
\hline \multirow[b]{2}{*}{ Variable } & \multicolumn{2}{|c|}{ Follicular waves, ${ }^{2}$ no. } & \multirow[b]{2}{*}{$\mathrm{SE}$} & \multirow[b]{2}{*}{$P$-value } \\
\hline & 2 & 3 & & \\
\hline Day of luteolysis & 17.1 & 18.3 & 0.7 & 0.131 \\
\hline Interval from luteolysis to ovulation, $\mathrm{d}$ & 5.0 & 5.6 & 0.4 & 0.276 \\
\hline Interovulatory interval, $\mathrm{d}$ & 21.2 & 23.0 & 0.7 & 0.024 \\
\hline \multicolumn{5}{|l|}{ Ovulatory follicle } \\
\hline Maximum diameter, $\mathrm{mm}$ & 17.0 & 15.5 & 0.5 & 0.026 \\
\hline Diameter at luteolysis, $\mathrm{mm}$ & 12.1 & 9.5 & 0.7 & 0.001 \\
\hline Interval emergence to ovulation, $\mathrm{d}$ & 9.2 & 7.6 & 0.4 & 0.001 \\
\hline Growth rate, $\mathrm{mm} / \mathrm{d}$ & 1.9 & 2.1 & 0.1 & 0.238 \\
\hline \multicolumn{5}{|l|}{ Luteal tissue volume, $\times 10^{3} \mathrm{~mm}^{3}$} \\
\hline Maximum & 15.6 & 13.3 & 1.0 & 0.101 \\
\hline Mean & 13.8 & 12.1 & 0.4 & 0.001 \\
\hline \multicolumn{5}{|l|}{ Plasma $\mathrm{P}_{4}$ concentration } \\
\hline Mean, ng/mL & 4.5 & 4.4 & 0.2 & 0.502 \\
\hline Peak, ng/mL & 6.4 & 6.2 & 0.3 & 0.400 \\
\hline At luteolysis, $\mathrm{ng} / \mathrm{mL}$ & 5.1 & 5.1 & 0.3 & 0.848 \\
\hline Area under the curve, $\mathrm{ng} \cdot \mathrm{d} / \mathrm{mL}$ & 54.6 & 61.1 & 3.9 & 0.213 \\
\hline
\end{tabular}

${ }^{1} \mathrm{~A}$ normal estrous cycle was defined as a cycle with a luteal phase between 10 and $30 \mathrm{~d}$ and in which the ovulatory wave was present at luteolysis.

${ }^{2}$ Data represent least squares means from estrous cycles with $2(\mathrm{n}=37)$ or $3(\mathrm{n}=36)$ follicular waves.

cystic structures in our cows were of follicular origin, which supports the results of Santos et al. (2000). Robinson et al. (2002) determined that the size of the first dominant follicle was greater for cows fed a diet rich in linoleic acid than for those fed a diet rich in linolenic acid but that after the first estrous cycle, there were no differences in diameter of the dominant follicle.

Administration of bST increased milk yield by 3.2 $\mathrm{kg} / \mathrm{d}$ (Carriquiry et al., 2009b), reduced peak $\mathrm{P}_{4}$, and doubled (9.8 vs. $20.6 \%$ ) the incidence of multiple ovulations in our study. This increase in multiple ovulations supports the 3 -fold increase ( 6.9 vs. $20.2 \%$ ) reported by Fricke and Wiltbank (1999) when milk yield increased from 31.7 to $50.7 \pm 0.7 \mathrm{~kg} / \mathrm{d}$. Wiltbank et al. (2000) proposed that increased milk yield increased blood flow through the liver, which increased steroid metabolism, and they proposed that the subsequent reduction in circulating steroid concentrations was the link between double ovulations and increased milk production. Although increased milk yield was associated with multiple ovulations and bST increased milk yield, bST decreased (Santos et al., 2000), did not change (Kirby et al., 1997), or increased (Jimenez-Krassel et al., 1999) the incidence of multiple ovulations. Therefore, effects of bST on the incidence of multiple ovulations are likely influenced by interactions with other factors.

The trend we observed for a relationship between increased plasma IGF-I and early onset of estrous supports reports of positive associations between circulating IGF-I and reproductive function (Lucy, 2000) and a potentially beneficial role of bST for the onset of estrous activity in early lactation. Although bST induced an increase in IGF-I by 28 DIM (2 wk after treatment initiation; Carriquiry et al., 2009b), it did not alter onset of estrous activity in this study.

The interactions of dietary n-6/n-3 fatty acid ratio and $\mathrm{bST}$ on the number of class 1 follicles and the opposing effects of AF (decreasing) and bST (increasing) on the number of class 2 follicles indicated that treatments affected follicular recruitment. When combined, the number of class 2 and class 3 follicles was greater in the bST-treated cows. These results indicate that the number of recruited follicles was increased by bST, which agrees with the trend for more ovulatory follicles per cycle in the bST-treated cows. However, the similar number of large class 4 follicles among treatments indicated that neither dietary $n-6 / n-3$ fatty acid ratio nor bST had an effect on the number or size of the dominant follicles.

Cows fed fat supplements enriched in linoleic acid (18:2, n-6) had similar (Petit et al., 2004; Ponter et al., 2006) or greater (Robinson et al., 2002) numbers of medium-sized ( 5 to $10 \mathrm{~mm}$ ) follicles compared with cows fed fat supplements enriched in linolenic acid (18:3, n-3). Our results support the lack of effect of the dietary n-6/n-3 fatty acid ratio on the number of small $(<5 \mathrm{~mm})$ or large $(>10 \mathrm{~mm})$ follicles reported by others (Petit et al., 2002, 2004; Ponter et al., 2006). Increased numbers of medium-sized follicles in cows fed diets enriched with linoleic acid were associated with increased plasma insulin or IGF-I (Robinson et al., 2002), and these hormones stimulate follicular growth (Lucy, 2000). In our study, plasma IGF-I was reduced in cows fed SS and there was no effect of diet on plasma glucose 
concentrations during the first 90 DIM (Carriquiry et al., 2009b). Although we detected an interaction of bST and fat on the number of class 1 follicles, this has apparently not been detected previously.

An increased number of class 1 follicles (Lucy et al., 1993), class 2 follicles (De La Sota et al., 1993; Lucy et al., 1993; Kirby et al., 1997), class 3 follicles (De La Sota et al., 1993), and dominant follicles (Jimenez-Krassel et al., 1999) occurred when lactating (De La Sota et al., 1993; Lucy et al., 1993; Kirby et al., 1997) and nonlactating cows (De La Sota et al., 1993) were treated with bST. In contrast, Santos et al. (2000) reported that class distribution of the follicular population in lactating cows was not affected by bST administration.
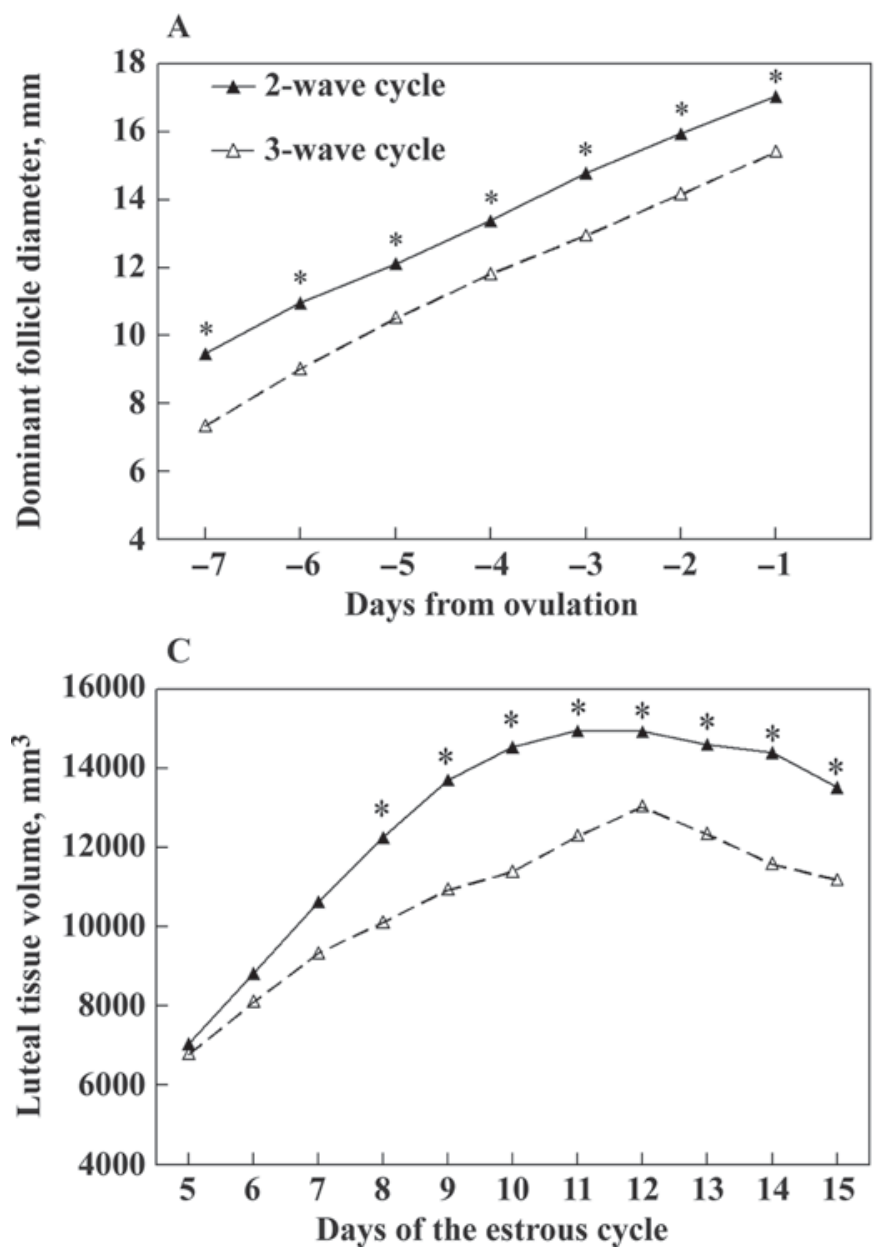

The increased number of class 3 follicles with time after calving in our study was observed previously (Lucy et al., 1991; Kendrick et al., 1999). Although in our study the number of small follicles $(\leq 5 \mathrm{~mm})$ remained unchanged as lactation progressed, others have reported a decrease (Lucy et al., 1991) or an increase (Kendrick et al., 1999) in these follicles.

\section{Ovarian Activity-Normal Estrous Cycles}

The interovulatory interval $(22.1 \pm 0.9 \mathrm{~d})$ in cows with normal cycles was consistent with the estimate Sartori et al. (2004) derived from a review of 7 studies (230 estrous cycles from 224 cows). Our results support

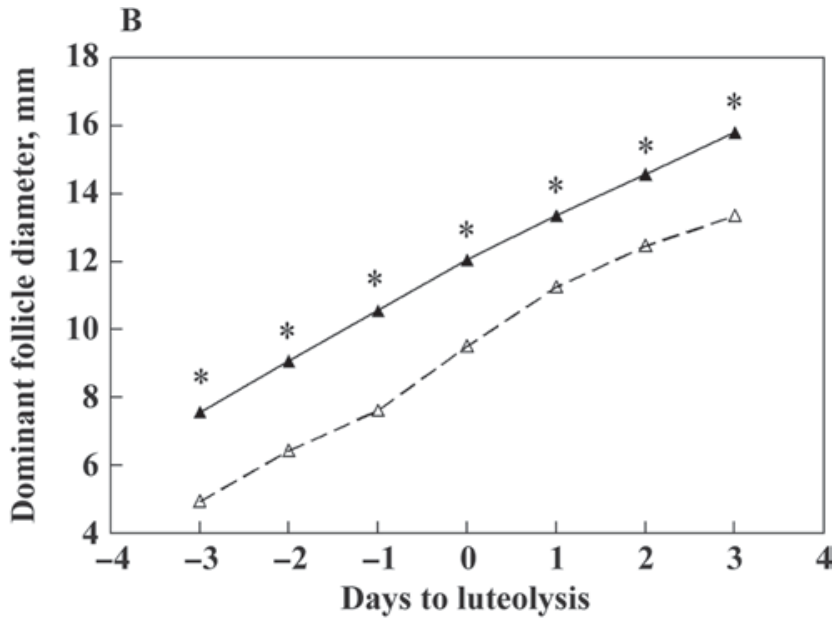

D

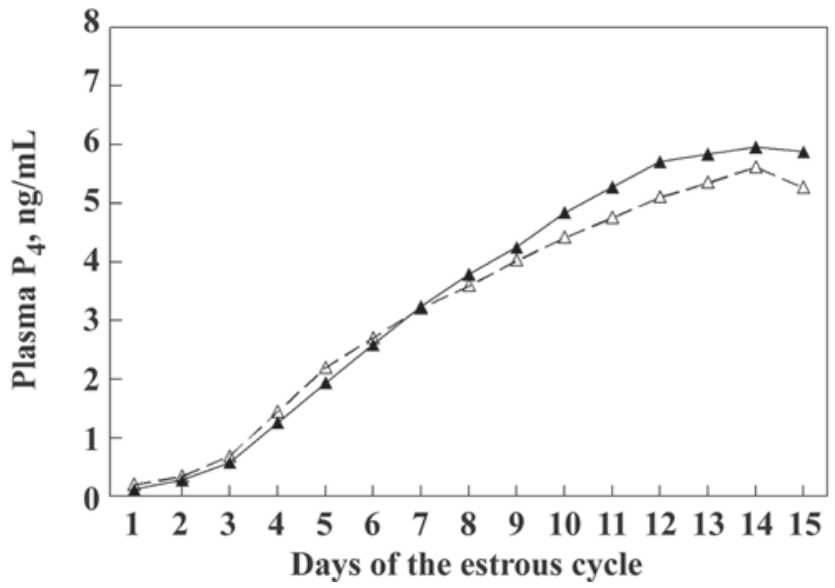

Figure 3. Effect of number of follicular waves per estrous cycle on dominant follicle diameter (mm) normalized to day of ovulation (A) or luteolysis (B), luteal tissue volume from d 5 to 14 of the cycle $(\mathrm{C})$, and plasma progesterone $\left(\mathrm{P}_{4}\right)$ concentrations from $\mathrm{d} 1$ to 14 of the cycle (D). The solid triangles and solid line identify the 2-wave cycles, and the open triangles and dashed line identify the 3-wave cycles. Luteolysis was considered to occur on the day before serum $\mathrm{P}_{4}$ concentration decreased by more than $50 \%$ from the maximum $\mathrm{P}_{4}$ concentration in the cycle, and was identified as d 0 . Cows were from 4 treatments derived from a $2 \times 2$ combination of supplemental fat source [whole, high-oil sunflower seeds $(\mathrm{n}-6 / \mathrm{n}-3$ fatty acids $=4.6)$ or a mixture of Alifet-High Energy and Alifet-Repro (Alifet USA, Cincinnati, OH; n-6/n-3 fatty acids = 2.6)] beginning at calving and with 0 or $500 \mathrm{mg}$ of bST administered every $10 \mathrm{~d}$ from 12 to 70 DIM and at 14-d intervals thereafter. Data represent least squares means for Holstein cows with $2(\mathrm{n}=37)$ or $3(\mathrm{n}=36)$ follicular waves per cycle. Only results from cycles in cows with a luteal phase between 10 and $30 \mathrm{~d}$ in which the ovulatory wave was present at luteolysis were summarized. Standard error of the mean was 0.6 mm for dominant follicle diameter whether normalized to luteolysis or ovulation, $1,177 \mathrm{~mm}^{3}$ for luteal tissue volume, and $0.2 \mathrm{and} 0.3 \mathrm{ng} / \mathrm{mL}$ for plasma $\mathrm{P}_{4}$ from d 1 to 14 of the cycle and to luteolysis, respectively. Symbols indicate differences between 2 - and 3 -wave cycles $(* P<0.05)$. 
those of others in that the interovulatory interval was not affected by bST when cows were treated with bST in either early (Santos et al., 2000) or mid- (Kirby et al., 1997) lactation. The combination of an increase in dietary n-3 fatty acids and bST administration (AFY) increased the number of cycles with 3 follicular waves, which decreased the age of the oocyte at ovulation. This could be beneficial for conception because Lucy (2000) and Townson et al. (2002) indicated that pregnancy rates were greater when cows had 3 -wave cycles because of the prolonged period of follicular development in 2-wave cycles.

Ovulatory follicle diameters varied from 11 to $21 \mathrm{~mm}$ and were similar to those in cows undergoing spontaneous estrous (Lucy et al., 1991). Feeding n-3 fatty acids has increased the size of the ovulatory follicle (Ambrose et al., 2006). The larger ovulatory follicles in our AFN cows were associated with greater follicle growth rates for cows fed AF, but intervals between emergence of the ovulatory follicle and ovulation and between luteolysis and ovulation were not affected by treatment. Although the maximum ovulatory follicle size was greater in our AFN cows and follicular growth rate was greater when cows consumed AF, the interval of follicular growth and mean follicle diameter at luteolysis were not altered by treatment. The slope of the regression line for the relationship between circulating $\mathrm{P}_{4}$ and $\mathrm{CL}$ volume was less for cows treated with bST in our study, which supports the reduced $\mathrm{P}_{4}$ peak for bST-treated cows despite the lack of effect of bST on maximum luteal tissue volume. Variation in CL volume accounted for $36 \%$ of the variation in circulating $\mathrm{P}_{4}$ concentration in cows not treated with bST but accounted for only $21 \%$ of the variation in bST-treated cows.

The opposite effects of bST in the interaction of diet and bST on mean CL volume (decreasing in AF cows, increasing in SS cows) and on $\mathrm{P}_{4}$ AUC (decreasing in SS cows, increasing in AF cows) likely contributed to these differences in the relationship of circulating $\mathrm{P}_{4}$ and CL volume in cows treated or not treated with bST. The bST-induced reduction in $\mathrm{P}_{4} \mathrm{AUC}$ in SS cows might have been influenced by the greater negative energy balance of the SSY cows (Carriquiry et al., 2009b) because Santos et al. (2000) detected reduced $\mathrm{P}_{4}$ concentrations when lactating cows were in negative energy balance. Although the bST-treated cows produced more milk, DMI was not altered. Therefore, the impact of increased steroid metabolism was likely less in our study than in studies conducted by Wiltbank and colleagues (Sangsritavong et al., 2002; Sartori et al., 2002, 2004).

Our results support studies that reported the dietary n-6/n-3 fatty acid ratio did not modify $\mathrm{P}_{4}$ concentration in blood (Mattos et al., 2002; Robinson et al., 2002;
Ambrose et al., 2006) or milk (Ponter et al., 2006). Although cows that consumed increased amounts of EPA and DHA produced less plasma $\mathrm{PGF}_{2 \alpha}$ metabolite after stimulation with estradiol and oxytocin, plasma $\mathrm{P}_{4}$ concentrations did not differ from those of nonsupplemented cows during the first $15 \mathrm{~d}$ of the estrous cycle (Mattos et al., 2002). Similarly, no differences in plasma or milk $\mathrm{P}_{4}$ concentrations were detected when dietary n-6/n-3 fatty acid ratios were altered from 0.7 to 9.2 (Petit et al., 2004) or from 0.4 to 5.3 (Ponter et al., 2006).

The longer interovulatory interval in 3-wave cycles and the similar interval between luteolysis and ovulation in 2- and 3-wave cycles in our study support results in dairy cows (Townson et al., 2002). The ovulatory follicle grew at the same rate in 2- and 3-wave cycles, but grew for approximately $1.6 \mathrm{~d}$ less in 3 -wave cycles so that its size at ovulation was reduced. Sartori et al. (2004) reported a shorter interval between emergence of the ovulatory follicle and ovulation but a greater follicular growth rate in 3-wave cycles, which resulted in an ovulatory follicle that was similar to the size of the ovulatory follicle from 2-wave cycles.

Circulating $\mathrm{P}_{4}$ concentrations in our study during the first $15 \mathrm{~d}$ of the estrous cycle did not differ between cows with 2- or 3-wave cycles and support the finding of Townson et al. (2002), who reported similar results in lactating cows. Despite similar circulating $\mathrm{P}_{4}$ concentrations, size of the ovulatory follicle and mean luteal tissue volume from d 5 to 15 of the estrous cycle were reduced in our cows with 3 -wave cycles. Previous studies have determined that the size of the ovulatory follicle and subsequent luteal volume are related positively (Sartori et al., 2002). Sartori et al. (2004) reported no difference in CL volume from d 3 to 14 of the estrous cycle and reported a similar pattern of luteal regression in terms of CL size and circulating $\mathrm{P}_{4}$ for 2 - and 3 -wave cycles in heifers.

\section{CONCLUSIONS}

Initiation of bST administration at 12 DIM and a diet enriched with n-3 fatty acids altered the follicular population and dynamics during the first 90 DIM. The number of class 1 follicles decreased in bST-treated cows, which indicates that bST increased the number of recruited follicles. Feeding n-3 fatty acids increased growth rate of the ovulatory follicle and increased the size of the ovulatory follicle in the absence of bST. In addition, the number of follicular waves within an estrous cycle can be modified by feeding n-3 fatty acids and by bST administration. In particular, results indicate that bST interacts with dietary n-3 fatty acids to increase the incidence of estrous cycles with 3 follicular waves, which would produce smaller follicles and younger 
oocytes. These changes could benefit reproductive performance. Further studies using larger numbers of cows are needed to determine if fertility is also affected.

\section{ACKNOWLEDGMENTS}

Excellent animal care and courteous assistance throughout the study were provided by the staff at the University of Minnesota, Northwest Research and Outreach Center (Crookston, MN). The authors thank Monsanto Co. (St. Louis, MO) for providing the recombinant bST (Posilac) and Alifet USA (Cincinnati, OH) for providing the Alifet-High Energy and Alifet-Repro.

\section{REFERENCES}

Allen, M. S. 2000. Effects of diet on short-term regulation of feed intake by lactating dairy cattle. J. Dairy Sci. 83:1598-1624.

Ambrose, D. J., J. P. Kastelic, R. Corbett, P. A. Pitney, H. V. Petit, J. A. Small, and P. Zalkovic. 2006. Lower pregnancy losses in lactating dairy cows fed a diet enriched in $\alpha$-linolenic acid. J. Dairy Sci. 89:3066-3074.

Beam, S. W., and W. R. Butler. 1997. Energy balance and ovarian follicle development prior to the first ovulation postpartum in dairy cows receiving three levels of dietary fat. Biol. Reprod. $56: 133-142$.

Carriquiry, M., W. J. Weber, C. R. Dahlen, G. C. Lamb, L. H. Baumgard, and B. A. Crooker. 2009a. Fatty acid composition of milk from multiparous Holstein cows treated with bovine somatotropin and fed n-3 fatty acids in early lactation. J. Dairy Sci. 92:4865-4875

Carriquiry, M., W. J. Weber, C. R. Dahlen, G. C. Lamb, L. H Baumgard, and B. A. Crooker. 2009b. Production response of multiparous Holstein cows treated with bovine somatotropin and fed diets enriched with n-3 or n-6 fatty acids. J. Dairy Sci. 92:.4852-4864

Carriquiry, M., W. J. Weber, S. R. Sanders, L. H. Baumgard, and B. A. Crooker. 2008. In vitro biohydrogenation of protected dietary fats. Anim. Feed Sci. Technol. 141:339-355.

De La Sota, R. L., M. C. Lucy, C. R. Staples, and W. W. Thatcher. 1993. Effects of recombinant bovine somatotropin (Sometribove) on ovarian function in lactating and nonlactating dairy cows. J. Dairy Sci. 76:1002-1013.

Fricke, P. M., and M. C. Wiltbank. 1999. Effect of milk production on the incidence of double ovulation in dairy cows. Theriogenology 52:1133-1143.

Garverick, H. A. 1997. Ovarian follicular cysts in dairy cows. J. Dairy Sci. 80:995-1004.

Jimenez-Krassel, F., M. Binelli, H. A. Tucker, and J. J. Ireland 1999. Effect of long-term infusion with recombinant growth hormone-releasing factor and recombinant bovine somatotropin on development and function of dominant follicles and corpora lutea in Holstein cows. J. Dairy Sci. 82:1917-1926.

Kendrick, K. W., T. L. Bailey, A. S. Garst, A. W. Pryor, A. Ahmadzadeh, R. M. Akers, W. E. Eyestone, R. E. Pearson, and G. Gwazdauskas. 1999. Effects of energy balance on hormones, ovarian activity, and recovered oocytes in lactating Holstein cows, using transvaginal follicular aspiration. J. Dairy Sci. 82:1731-1740.

Kirby, C. J., M. F. Smith, D. H. Keisler, and M. C. Lucy. 1997. Follicular function in lactating dairy cows treated with sustained release bovine somatotropin. J. Dairy Sci. 80:273-285.

Lucy, M. C. 2000. Regulation of ovarian follicular growth by somatotropin and insulin-like growth factors in cattle. J. Dairy Sci. 83:1635-1647.
Lucy, M. C., R. L. De La Sota, C. R. Staples, and W. W. Thatcher. 1993. Ovarian follicular populations in lactating dairy cows treated with recombinant bovine somatotropin (Sometribove) or saline and fed diets differing in fat content and energy. J. Dairy Sci. 76:1014-1027.

Lucy, M. C., C. R. Staples, F. M. Michel, and W. W. Thatcher. 1991. Energy balance and size and number of ovarian follicles detected by ultrasonography in early postpartum dairy cows. J. Dairy Sci. 74:473-482.

Mattos, R., C. R. Staples, J. Williams, A. Amorocho, M. A. McGuire, and W. W. Thatcher. 2002. Uterine, ovarian and production responses of lactating cows to increasing dietary concentration of Menhaden fish meal. J. Dairy Sci. 85:755-764.

Moallem, U., M. Kaim, Y. Folman, and D. Sklan. 1997. Effect of calcium soaps of fatty acids and administration of somatotropin in early lactation on productive and reproductive performance of high producing dairy cows. J. Dairy Sci. 80:2127-2136.

Moreira, F., C. Orlandi, C. A. Risco, R. Mattos, F. Lopes, and W. W. Thatcher. 2001. Effects of presynchronization and bovine somatotropin on pregnancy rates to a timed artificial insemination protocol in lactating cows. J. Dairy Sci. 84:1646-1659.

Opsomer, G., Y. T. Grohn, J. Hertl, M. Coryn, H. Deluyker, and A. de Kruif. 2000. Risk factors for postpartum ovarian dysfunction in high producing dairy cows in Belgium: A field study. Theriogenology $53: 841-857$

Petit, H. V., R. J. Dewhurst, N. D. Scollan, J. G. Proulx, M. Khalid, W. Haresign, H. Twagiramungu, and G. E. Mann. 2002. Milk production and composition, ovarian function and prostaglandin secretion of dairy cows fed omega-3 fats. J. Dairy Sci. 85:889899.

Petit, H. V., C. Germiquet, and D. Lebel. 2004. Effect of feeding whole, unprocessed sunflower seeds and flaxseed on milk production, milk composition, and prostaglandin secretion in dairy cows. J. Dairy Sci. 87:3889-3898.

Ponter, A. A., A.-E. Parsy, M. Saadé, J.-P. Mialot, C. Ficheux, C. Duvaux-Ponter, and B. Grimard. 2006. Effect of a supplement rich in linolenic acid added to the diet of post partum dairy cows on ovarian follicle growth, and milk and plasma fatty acid compositions. Reprod. Nutr. Dev. 46:19-30.

Robinson, R. S., P. G. A. Pushpakumara, Z. Cheng, A. R. Peters, D R. E. Abayasekara, and D. C. Wathes. 2002. Effects of dietary polyunsaturated fatty acids on ovarian and uterine function in lactating dairy cows. Reproduction 124:119-131.

Sangsritavong, S., D. K. Combs, R. Sartori, L. E. Armentano, and M. C. Wiltbank. 2002. High feed intake increases liver blood flow and metabolism of progesterone and estradiol-17 $\beta$ in dairy cattle. J. Dairy Sci. 85:2831-2842.

Santos, J. E. P., J. T. Huber, C. B. Theurer, L. G. Nussio, C. B. Nussio, M. Tarazon, and R. O. Lima-Filho. 2000. Effects of grain processing and bovine somatotropin on metabolism and ovarian activity of dairy cows during early lactation. J. Dairy Sci. 83:1004-1015.

Sartori, R., G. J. M. Rosa, and M. C. Wiltbank. 2002. Ovarian structures and circulating steroids in heifers and lactating cows in summer and lactating and dry cows in winter. J. Dairy Sci. $85: 2813-2822$

Sartori, R., J. M. Haughian, R. D. Shaver, G. J. M. Rosa, and M. C. Wiltbank. 2004. Comparison of ovarian function and circulating steroids in estrous cycles of Holstein heifers and lactating cows. J. Dairy Sci. 87:905-920.

Staples, C. R., J. M. Burke, and W. W. Thatcher. 1998. Influence of supplemental fats on reproductive tissues and performance of lactating cows. J. Dairy Sci. 81:856-871.

Townson, D. H., P. C. W. Tsang, W. R. Butler, M. Frajblat, L. C. Griel Jr., C. J. Johnson, R. A. Milvae, G. M. Niksic, and J. L. Pate. 2002. Relationship of fertility to ovarian follicular waves before breeding in dairy cattle. J. Anim. Sci. 80:1053-1058.

Wiltbank, M. C., P. M. Fricke, S. Sangsritavong, R. Sartori, and O. J. Ginther. 2000. Mechanisms that prevent and produce double ovulation in dairy cattle. J. Dairy Sci. 83:2998-3007. 